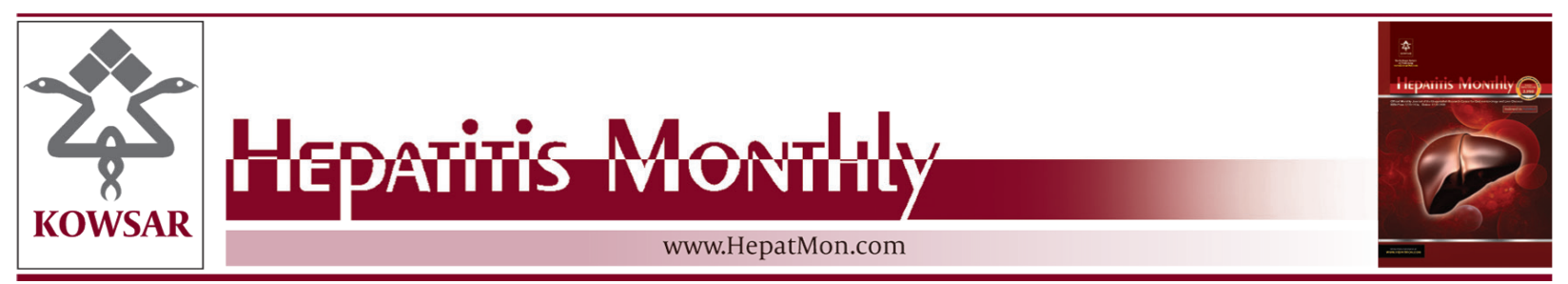

\title{
Activation of Nrf2-Antioxidant Response Element Mediated Glutamate Cysteine Ligase Expression in Hepatoma Cell line by Homocysteine
}

\author{
Monireh Mani ${ }^{1}$, Shahnaz Khaghani ${ }^{1}{ }^{1,}$, Taghi Gol Mohammadi ${ }^{1}$, Zahra Zamani ${ }^{2}$, Kayhan \\ Azadmanesh ${ }^{3}$, Reza Meshkani ${ }^{1}$, Parvin Pasalar ${ }^{1}$, Ehsan Mostafavi ${ }^{4}$ \\ ${ }^{1}$ Department of Biochemistry, School of Medicine, Tehran University of Medical Science, Tehran, IR Iran \\ 2 Department of Biochemistry, Pasteur Institute, Tehran, IR Iran \\ ${ }^{3}$ Department of Virology, Pasteur Institute, Tehran, IR Iran \\ ${ }^{4}$ Department of Epidemiology, Pasteur Institute, Tehran, IR Iran \\ ${ }^{*}$ Corresponding author: Shahnaz Khaghani, Department of Biochemistry, School of Medicine, Tehran University of Medical Science, Tehran, IR Iran. Tel.: \\ +98-2188953004, Fax:+98-2164053384, E-mail: shanazkhaghani@yahoo.com.
}

\begin{abstract}
A B S T R A C T
Background: Homocysteine is a sulfur-containing amino acid which formed (mainly in the liver) during the metabolism of methionine. Prior studies indicated the important role of hyperhomocysteinemia in pathogenesis and progression of alcoholic liver disease, liver steatosis and cirrhosis. One of the most important mechanisms by which homocysteine promote the development of hepatic injury is oxidative stress. Transcription factor Nrf2-mediated antioxidant response, represents critical cellular defense mechanism that serves to maintain intracellular redox homeostasis and limit oxidative stress. Glutamate cysteine ligase catalytic(GCLc) is rate limiting enzyme in the synthesis of glutathione, an important endogenous antioxidant.

Objectives: This study was conducted to investigate whether homocysteine induces the Nrf2 dependent expression of GCLc in hepatoma cell line (HepG2) and whether this induction is mediated by antioxidant response element (ARE) which present within its promoter.

Materials and Methods: Glutathione (GSH) content was measured by flow cytometry. Using electro mobility shift assay (EMSA) and western blotting, ARE-binding activity of Nrf2 for GCLc was demonstrated. Real time RT-PCR and western blotting were performed to evaluate whether homocysteine was able to induce mRNA and protein expression of GCL.

Results: Exposure of HepG2 cells to $50 \mu \mathrm{MD} /$ L homocysteine and western blotting of nuclear extracts revealed that Nrf2 is strongly stabilized and became detectable in nuclear extracts. EMSA demonstrated increased binding of Nrf2 to oligomers containing GCL promoter - specific ARE -binding site.A time- dependent increase in the gene and protein expression of GCL was observed. Additionally, GSH, which is prime scavenger of free radicals in cells, decreased initially. Elevation of GSH, following the initial decline, closely correlated with gene expression profile of GCLc, which is a rate-limiting enzyme in GSH synthesis.
\end{abstract}

Conclusions: Altogether, we provide direct evidence that homocysteine activates Nrf2-mediated antioxidant response, which protects HepG2 cells from oxidative damage.

Keywords: HepG2 Cells; Oxidative Stress; Homocysteine

Copyright (@) 2013, Kowsar Corp.; Published by Kowsar Corp.

Article type: Research Article; Received: 01 Oct 2012; Revised: 11 Dec 2012; Accepted: 31 Dec 2012; Epub: 20 Apr 2013

-Implication for health policy/practice/research/medical education:

Induction of Nrf2-ARE pathway and consequently synthesis of GCL and glutathione which is the most important non-enzymatic anti oxidant defense system in hepatic cells, could be considered as a therapeutic strategy for the treatment of the patients with severe hyperhomocysteinemia which have progressive hepatic steatosis and cirrhosis.

Please cite this paper as:

Mani M, Khaghani SH, Gol Mohammadi T, Zamani Z, Azadmanesh K, Meshkani R, et al. Activation of Nrf2-Antioxidant Response Element Mediated Glutamate Cysteine Ligase Expression in Hepatoma Cell line by Homocysteine. Hepat Mon. 2013; 13(5):e8394. DOI: 10.5812/hepatmon.8394

Copyright @ 2013, Kowsar Corp.; Published by Kowsar Corp.

This is an Open Access article distributed under the terms of the Creative Commons Attribution License (http://creativecommons.org/licenses/by/3.0), which permits unrestricted use, distribution, and reproduction in any medium, provided the original work is properly cited. 


\section{Background}

Hyperhomocysteinemia (HHcy) has been implicated as a risk factor for atherosclerosis, cerebrovascular and peripheral vascular diseases (1-3). An increasing body of data links HHcy to hepatic dysfunctions. Elevation of homocysteine levels due to insult in homocysteine metabolism is observed in patients with liver cirrhosis and chronic alcohol consumption $(4,5)$. The enzymes 5,10-methylenetetrahydrofolate reductase (MTHFR) and cystathionine $\beta$ synthase (CBS) play critical roles in regulating plasma homocysteine. Nutritional deficiency and mutations in enzymes which remove homocysteine lead to HHcy $(6,7)$. One of the clinical manifestations of the patients with CBS and MTHFR deficiency is hepatic steatosis and fibrosis (8-10). The underlying mechanisms contributing the pathogenesis of liver injury to HHcy are still poorly understood and may be multifactorial. Studies on the mechanisms of homocysteine associated disorders have suggested that homocysteine induced Oxidative stress might play a major role in the pathology of damage (11-13). Induction of glutamate cysteine ligase catalytic (GCLC) which is a member of a family of antioxidant/ detoxification enzymes is important to maintain cellular redox homeostasis and reduce oxidative damage. GCLc is a rate-limiting enzyme in glutathione (GSH) synthesis. Induction of this enzyme is through a cis-acting element in the promoter region known as the antioxidant response element (ARE). AREs are known to play essential roles in regulating the cellular responses to oxidative stress (14, 15). GSH is a major intracellular antioxidant in mammals, and the liver is the major site of its synthesis from the point of view of quantity (16). In cells exposed to oxidative stress, expression of the nuclear factor erythroid-derived 2-like 2 (Nrf2) is enhanced. Nrf2 positively regulates the transcriptional activation of a number of genes in that their expression is essential to protect cells against loss of viability under homeostatic conditions (17). There has been no assessment as to whether Nrf2 is involved in the oxidative stress response induced by homocysteine in liver and a direct link between homocysteine mediated GCLc induction and activation of Nrf2 expression via stimulation of ARE binding activity remains to be examined.

\section{Objectives}

In this study, we analyzed the involvement of Nrf2 and ARE activation in GCL induction by homocysteine in hepatoma cell line.

\section{Materials and Methods}

\subsection{Study design}

This experimental study was performed to determine the effect of homocysteine on mRNA and protein expression of HO-1 in HepG2 cells and the role of Nrf2-ARE pathway in this induction. HepG2 cells were cultured by routine method. The cells were divided into two groups: control and treated with homocysteine. HO-1 expression was measured by real time PCR and protein expression by western blotting. Glutathione content was examined by flowcytometry.

\subsection{Cell Culture, Treatment and Cell Viability Assay}

The HepG2 cells (National Cell Bank, Pasteur Institute of Iran) were cultured in Dulbecco's modified Eagle's medium (DMEM) supplemented with $10 \%$ fetal calf serum and $100 \mathrm{u} / \mathrm{ml}$ penicillin $\mathrm{G}$ sodium, $100 \mu \mathrm{g} / \mathrm{ml}$ streptomycinand L-glutamine in humidified atmosphere in $5 \% \mathrm{CO}_{2}$ at $37^{\circ} \mathrm{C}$. For RNA extraction and glutathione detection, the cells were seeded at the density of $5 \times 10^{5}$ per well in 6 well culture plates. For isolation of whole cell and nuclear protein extract, cells were plated at a density of $2 \times 10^{6}$ in 25 $\mathrm{cm}^{2}$ flasks. The culture media were replaced with fresh media before different treatments. The untreated cells were used as controls. The cells were treated for $15 \mathrm{~min}$, $30 \mathrm{~min}, 45 \mathrm{~min}, 3 \mathrm{~h}, 6 \mathrm{~h}$ and $9 \mathrm{~h}$ with homocysteine. Homocysteine (Sigma Chemical Co, USA) was used as D/L homocysteine at a final concentration of $50 \mu \mathrm{M}$, which correspond to $25 \mu \mathrm{ML}$ homocysteine. For cell viability assay HepG2 cells $\left(1 \times 10^{6}\right.$ cells $\left./ \mathrm{ml}\right)$ were incubated in control or test medium supplemented with $5 \%$ fetal calf serum at $37^{\circ} \mathrm{C}$ for $18 \mathrm{~h}$. Cell viability was assessed by counting cells on a hemocytometer after suspension in $\mathrm{PBS}(\mathrm{pH}=7)$ containing $0.5 \%$ trypan blue stain. Data shows the means \pm SD from three independent experiments.

\subsection{Intercellular Glutathione Content}

Glutathione content of the cells was measured using the ThiolTracker Violet GSH detection reagent (Invitrogen/Molecular probes, Eugene, OR) according to the manufacturer's protocol. Cells were seeded in six-well plates, incubated overnight and treated the following day. Subsequent to homocysteine exposure for the indicated times (15 min,30 min,45 min, 3h,6h,9h), the cells were washed with PBS and incubated in Dulbecco's PBS containing $10 \mu \mathrm{M}$ (final concentration) ThiolTracker Violet for $30 \mathrm{~min}$ at $37^{\circ} \mathrm{C}$. Then cells were analyzed on a Flow cytometer (Partec, Germany). Analysis of cellular GSH content was restricted to PI negative intact cells.

\subsection{Preparation of Total RNA and Real Time Quan- titative RT-PCR}

Total RNA was isolated from HepG2 cells using Rneasy cell mini kit (QIAGEN GmbH, Hilden, Germany) according to the manufacturer's protcol. Quantification and purity of RNA samples were assessed by A260/A280 absorption, and RNA samples with ratios above 1.8 were stored at $-70^{\circ} \mathrm{C}$ for further analysis. Three micrograms of total RNA were subjected to reverse transcription using Quantitect Revese Transcription Kit (Fermentase, Vilnius, Lithuania). Real-time quantitative RT-PCR was done using SYBR premix Taq (Takara, Japan) and primer for GCLc (QT00037310, QIAGEN GmbH, Hilden, Germany). The transcript for the 
constitutive gene product $\beta$-actin (QT01680476, QIAGEN $\mathrm{GmbH}$, and Hilden, Germany) was used as endogenous control for data normalization. Each sample type was run in duplicate and each experiment was performed four times. Each cycle consisted of denaturation at $95^{\circ} \mathrm{C}$ for $5 \mathrm{sec}$ and combined annealing and extension at $60^{\circ} \mathrm{C}$ for $30 \mathrm{sec}$. The expression levels of the gene were quantified with REST 2009 software.

\subsection{Preparation of Protein Extract for Western Blot- ting}

For preparation of nuclear extracts, cells were homogenized in lysis buffer, consisting of $10 \mathrm{mM}$ HEPES $(\mathrm{pH}=$ 7.9),1.5 mM MgCl2,10 mM KCl,0.5 mM dithiothreitol(DTT) and protease inhibitor cocktail (Roche, Mannheim, Germany). Subsequently, homogenate was then centrifuged at $3000 \mathrm{rpm}$ for $10 \mathrm{~min}$ at $4^{\circ} \mathrm{C}$. The resulting nuclear pellet was resuspended in $30 \mu \mathrm{l}$ of cold buffer $\mathrm{B}$, consisting of 5 mM HEPES ( $\mathrm{pH}=7.9$ ),1.5 mM MgCl2,0.2 mM EDTA,0.5 mM DTT, $26 \%$ glycerol and protease inhibitor. The suspension underwent centrifugation at $14800 \mathrm{~g}$ for $5 \mathrm{~min}$ at $4^{\circ} \mathrm{C}$. The protein concentration was measured by the Bradford method. For preparation of whole cell extract, cells were lysed in RIPA lysis buffer $(150 \mathrm{mM}$ sodium chloride, $1 \% \mathrm{~Np}-40,0.5 \%$ sodium deoxycholate, $0.1 \% \mathrm{SDS}, 50 \mathrm{mM}$ tris $\mathrm{pH}=8$ ) and protease inhibitor cocktail on ice. Lysates were incubated on ice for $10 \mathrm{~min}$ at $4^{\circ} \mathrm{C}$ and subsequently centrifuged at $9300 \mathrm{~g}$ for $10 \mathrm{~min}$. Finally, supernatants were saved and stored at $-70^{\circ} \mathrm{C}$. The amount of protein was measured by the Bradford method.

\subsection{Western Blotting Analysis}

Sample proteins from whole cell lysates $(30 \mu \mathrm{g})$ and nuclear extracts $(40 \mu \mathrm{g})$ were loaded on sodium dodecyl sulfate polyacrylamide gels ( $8 \%$ and $10 \%$ respectively). Separated proteins by SDS-PAGE were transferred to a nitrocellulose membrane and blocked. Immunoblot analysis was carried out using the following primary antibodies; anti GCLc (1/400) polyclonal antibody (abcam Co, UK), antiNrf2 (1/500) polyclonal antibody (abcam Co, UK). Antiß-actin (1/3000) polyclonal antibody and antilamin B (1/2000) polyclonal antibody (abcam Co, UK) were used for normalization of the data. HRP-conjugated goat-anti rabbit IgG were used as secondary antibody. Blots were developed using the enhanced chemiluminescence immunoblot detecting reagent (ECL plus Western blotting detection system, GE Healthcare). The intensity of bands was calculated with image J software (version 1.46a).

\subsection{Electrophoretic Mobility Shift Assay (EMSA)}

Nuclear extracts were prepared as described above. The synthetic complementary oligonucleotides 5'-GCACAAAGCGCTGAGTCACGGGGAGG-3'and 5'-CCTCCCCGTGACTCAGCGCTTTGTGC-3' (sigma, USA) were 3'-biotinylated using the biotin 3 '-end DNA labeling Kit (pierce) according to the manufacturer's instructions. The standard binding reaction mixture contained $50 \mathrm{ng} / \mu \mathrm{l}$ poly (dI-dc),0.05\% Nonidet P-40,5 mM MgCl2,10 mM EDTA, and $2.5 \%$ glycerol in $1 \mathrm{X}$ binding buffer (Lightshift chemiluminescent EMSA kit, Pierce), $20 \mathrm{f}$ M of biotin-end -labeled target DNA and $10 \mu \mathrm{g}$ of nuclear extract. The reaction mixture was incubated at $25^{\circ} \mathrm{C}$ for $20 \mathrm{~min}$. The DNA-protein complex was separated in a $5 \%$ polyacrylamide gel in $0.5 \mathrm{X}$ Tris borate/EDTA, and then transferred on to a positively charged nylon membrane in $0.5 \mathrm{X}$ Tris borate/EDTA at $100 \mathrm{~V}$ for $30 \mathrm{~min}$. The membrane was UV-cross-linked and the biotin end-labeled probe was detected with streptavidin-HRP using a luminol enhancer solution (Lightshift chemiluminescent EMSA kit) according to the manufacturer's instruction. For supershift assays, $1 \mu \mathrm{lof} 1 \mu \mathrm{g} / \mu \mathrm{l}$ Nrf2 antibody (SANTA CRUZ SC- $722 \mathrm{X}$ ) was added to the reaction mixture and incubated for $30 \mathrm{~min}$ at room temperature prior to electrophoresis. A 200-fold excess of unlabeled oligonucleotide (competitor) was added where necessary.

\subsection{Statistical Analysis}

SPSS version 16 was used for data analysis. Data were summarized using descriptive statistics (means \pm standard error). Significance of differences between control and treated groups was determined by one-way analysis of variance (ANOVA). LSD post-hoc analysis was performed for comparing the groups. For all analyses, P value less than 0.05 were considered significant.

\section{Results}

\subsection{Effect of Homocysteine on the Viability of HepG2 Cells}

To examine the effect of homocysteine on the viability of human hepatoma cells, HepG2 cells were incubated with $50 \mu \mathrm{MD} / \mathrm{L}$ homocysteine for up to $18 \mathrm{~h}$. Exposure of HepG2 cells $\left(1 \times 10^{6}\right.$ cells/ml $)$ to $50 \mu \mathrm{M}$ homocysteine had no effect on cell viability [Control (live cells: $93 \pm 0.7$ ) vs. treatment group with $50 \mu \mathrm{M}$ homocysteine (live cells: 93 $\pm 1.0)](\mathrm{P}=0.85)$.

\subsection{Homocysteine Alters GSH Level}

The intracellular GSH level was determined following treatment with homocysteine. Changes in intracellular GSH exhibited two phases (Figure 1). First, GSH content from $46 \%$ in untreated cells significantly decreased to about $19 \%$ and $35 \%$ within $15 \mathrm{~min}$ and $45 \mathrm{~min}$ of homocysteine exposure respectively. Then, the depleted GSH level began to recover and reached to $60 \%$ at $3 \mathrm{~h}$, and 76 $\%$ (maximum level) at 9 h. This reversal is likely caused by increased GCLc levels.The statistical analysis showed that there was a significant difference between GCLc protein level at $6 \mathrm{~h}$ and $9 \mathrm{~h}$ with controls $(\mathrm{P}<0.001)$. The statistical analysis also showed that there was a significant differ- 
ence between GCLc protein level in different treatment time periods $(\mathrm{P}<0.001)$.

Figure 1. Intercellular Levels of GSH Using Flow Cytometry in HepG2 Cells Exposed To Homocysteine

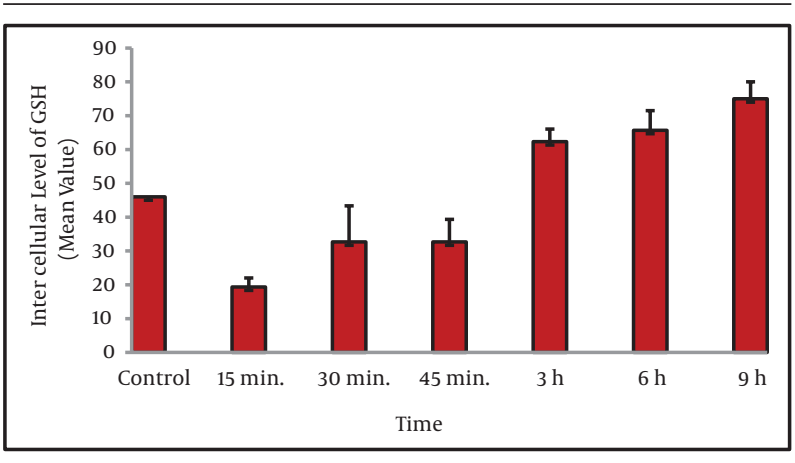

HepG2 cells were treated with $\mathrm{D} / \mathrm{L}$ homocysteine $(50 \mu \mathrm{M})$ for the indicated times, and harvested for flow cytometric analysis of intracellular glutathione content using mean channel fluorescence (MCF) of ThiolTracker Violet dye (TTV). Analysis of cellular GSH content was restricted to PI negative intact cells. Values are means \pm SE. Statistically different from control

\subsection{Homocysteine Induces GCLC $m R N A$ and Pro- tein Expression}

To evaluate whether homocysteine was able to induce GCLc mRNA expression, cells were treated with homocysteine and quantitative real-time RT-PCR analysis was performed.The inducing effect of homocysteine was observed after $3 \mathrm{~h}$ and $6 \mathrm{~h}$ of treatment. Levels of GCLc mRNA expression were increased 2.3 fold \pm 0.91 and 3 fold \pm 0.68 after $3 \mathrm{~h}$ and $6 \mathrm{~h}$ respectively (Figure 2). The statistical analysis showed that there was a significant difference between expression levels at $3 \mathrm{~h}$ and $6 \mathrm{~h}$ with $\operatorname{con}$ trol $(\mathrm{P}<$ $0.05)$. The statistical analysis also showed that there was a significant difference between expression levels in different treatment time periods $(\mathrm{P}=0.004)$.

Figure 2. Homocysteine Induces GCLc mRNA Expression

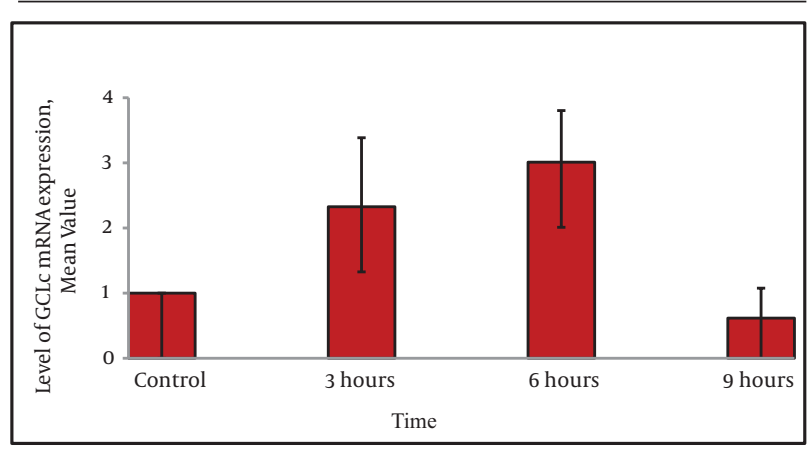

HepG2 cells were treated with $\mathrm{D} / \mathrm{L}$ homocysteine $(50 \mu \mathrm{M})$ for the indicated time points and GCLc mRNA levels were determined using quantitative real-time RT-PCR analysis. The bar graph shows the quantization of GCLc gene expression. Values are normalized to $\beta$-actin expression and represent the means $\pm S E$ of four separate experiments.
Figure 3. GCLc Protein Expression in HepG2 Cells Exposed to Homocysteine

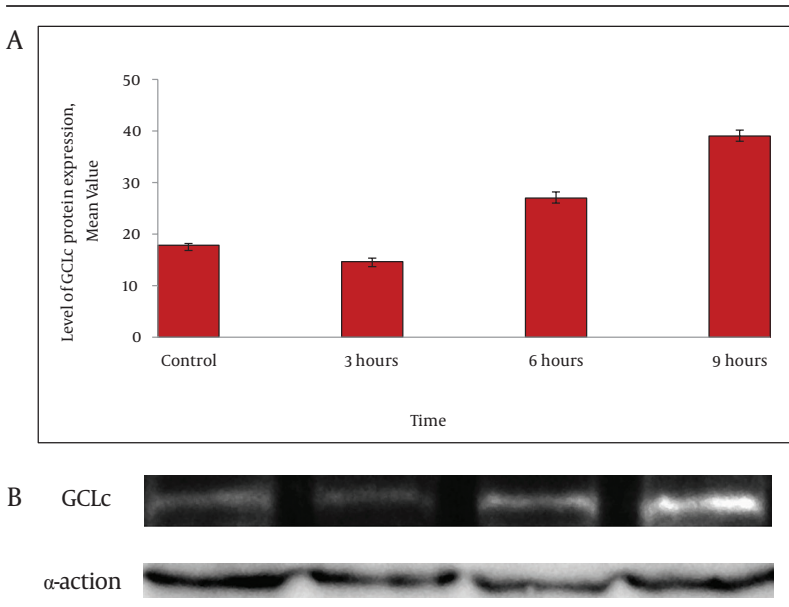

A) The protein levels were detected by western blotting. Values represent the means \pm SE of three separate experiments. The bar graph shows the quantization of GCLc protein B) Western blot analysis of GCLc in HepG2 cells. The cells were incubated with $50 \mu \mathrm{M}$ homocysteine for 3, 6 and $9 \mathrm{~h}$, and the cell extracts were electrophoresed, protein transferred, and blotted with the polyclonal antibody to GCLc. GCLc is a major band appearing at approximately $73 \mathrm{KD}$. $\beta$-actin was used as loading control.

To confirm the results obtained from real time RT-PCR experiment, western blot analysis was performed. The levels of GCLc protein expression started to decline $3 \mathrm{~h}$ after exposure to homocysteine and then increased by 1.6 fold and 2.3 fold in HepG 2 cells treated with homocysteine for $6 \mathrm{~h}$ and $9 \mathrm{~h}$ respectively (Figure 3 ).

\subsection{Homocysteine Increases the Nrf}

Incubation of the nuclear extracts after treatmentwith homocysteine, with ARE oligomers containing the GCLC promoter specific Nrf2-binding site resulted in the enhanced GCLc ARE-binding activity of Nrf2. The ARE-binding complex was increased at $45 \mathrm{~min}$ of homocysteine treatment and was maintained for 120 min (Figure $4 b$ ). Densitometric evaluation showed that levels of nuclear DNA binding of Nrf2 was increased by 1.4 fold, 2.4 fold and 3.8 fold after $45 \mathrm{~min}, 60 \mathrm{~min}$ and $120 \mathrm{~min}$ of treatment with homocysteine respectively. Addition of an anti-Nrf2 antibody indicates involvement of the Nrf2 transcription factor at this site. There was a significant difference between binding nuclear protein level at $1 \mathrm{~h}$ and $2 \mathrm{~h}$ compared to that of the control $(\mathrm{P}<0.001)$.

\subsection{Homocysteine Stimulates the Nrf}

The nuclear translocation of Nrf2 is an important mechanism that contributes towards gene expression. To explore whether homocysteine stimulated nuclear translocation of Nrf2, western blot analysis of nuclear extract was conducted. As shown in Figure $4 a$, homocysteine increased the nuclear accumulation of $\mathrm{Nrf} 2$, which reached 
a maximum at $45 \mathrm{~min}$ after homocysteine treatments. Densitometric evaluation showed that levels of nuclear Nrf2 increased by 1.3 fold, 1.92 fold and 2.21 fold in HepG2 cells treated with homocysteine after $15 \mathrm{~min}, 30 \mathrm{~min}$ and $45 \mathrm{~min}$ in compared to that of the control.

\section{Figure 4. Homocysteine Activates Nrf2-Mediated Antioxidant Response}

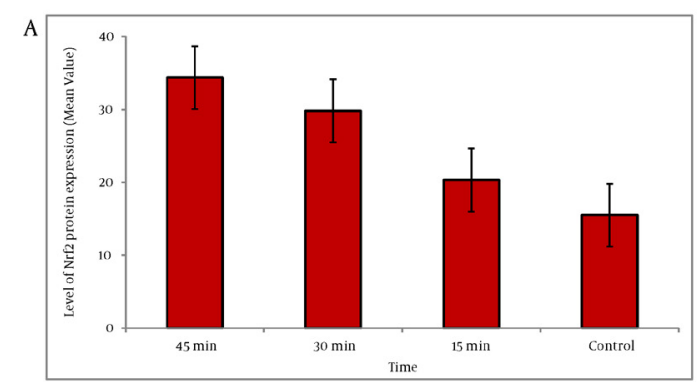

B $\operatorname{Lamin} B$

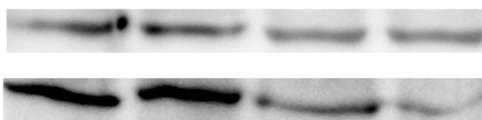

Nrf2

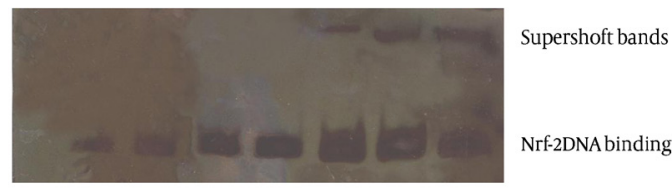

Cold oligonucleotide

$\operatorname{Nrf-2AB}$

Homocysteine

$$
\begin{aligned}
& \begin{array}{llllll}
- & - & - & - & - & +
\end{array} \\
& +\quad-\quad 45 \min \quad 60 \mathrm{~min} \quad 120 \mathrm{~min} \quad 45 \mathrm{~min} \quad 60 \mathrm{~min} \quad 20 \mathrm{~min}
\end{aligned}
$$

A) Nrf2 protein levels in nuclear fractions of HepG2 cells exposed to homocysteine $(50 \mu \mathrm{M})$ for the indicated time. The nuclear cell extracts were electrophoresed, protein transferred, and blotted with the polyclonal antibody Nrf2. Nrf2 is a major band appearing at approximately $68 \mathrm{kD}$. Lamin B was used as loading control. Quantification of band intensity was performed by Image J (version 1.46a). The bar graph shows the quantization of Nrf2 protein. Values represent the means \pm SE of three separate experiments B) Gel shift assay using oligomers containing the GCLc promoter-specific ARE-biding site and nuclear fractions of HepG2 cells that were exposed to homocysteine for the indicated time periods. Competitor $(200$ fold excess) and Nrf2 antibody were applied as indicated.

\section{Discussion}

Hyperhomocysteinemia has been suggested to have a role in pathogenesis of various diseases including hepatic dysfunction. Patients with hyperhomocysteinemia can develop hepatic steatosis and fibrosis (8-10). Previous studies have suggested that the pathophysiological effects of homocysteine are mediated via oxidative stress $(18,19)$ and oxidative stress plays an important role in different types of liver injury $(20,21)$. In the present study, we used HepG2 cells as a cellular model to consider the role of the self-protecting systems in the cells arise upon oxidative stress induced by homocysteine. We used 50 $\mu \mathrm{MD} / \mathrm{L}$ homocysteine for treatment of the cells. This concentration of homocysteine can be found in hyperho- mocysteinemic individuals (22). This concentration did not affect overall cell number or viability as determined by trypan blue assay. In the current study, we found that alterations of intracellular GSH caused by homocysteine exposure exhibited two phases, an elevation of intracellular GSH, following the initial decline within the first hour of homocysteine exposure. This initial decline might indicate that, to combat against oxidative stress induced by homocysteine, GSH might be the first line of antioxidant defense. We also found that, following the depletion of GSH, a compensatory increasing in GCLc mRNA and protein occurs. Using quantitative real time RT PCR analysis and western blotting, an increase in mRNA and protein levels for catalytic subunit of GCL could be demonstrated. This may at least in part be due to the relief in the feedback inhibition of the catalytic subunit of GCL and induction of this enzyme (23). The elevation of intracellular GSH following its initial decline, well correlated with increased expression of the GCLc which is a key antioxidant enzyme in regulation of GSH synthesis. Since the enzymes regulating GSH synthesis such as GCLc, are regulated at least in part by Nrf2, these results provided the direct evidence that Nrf2 can be activated by homocysteine. To elucidate the role of Nrf2 in transcriptional activation of ARE in response to homocysteine, electro mobility shift assay was performed. Using EMSA, we were able to demonstrate that homocysteine induces increased binding of nuclear proteins in HepG2 cells to ARE- containing oligonucleotide. This is in agreement with a recent study where homocysteine induced increased binding activity of the GCL-ARE in mouse macrophages (24). Consistent with the results of EMSA, western blot analysis showed that, Nrf2 nuclear proteins accumulation was increased after stimulation with homocysteine. This revealed that, transcriptional factor Nrf2 plays a critical role in cellular response against homocysteine induced stress oxidative. Our data also indicates that Nrf2 is rapidly stabilized and mobilized to the nucleus in response to homocysteine treatment. Induction of GCL expression under regulation of Nrf2-ARE is consistent with observations of Huang et al, who reported that upregulation of GCL expression inhibited oxidative stress in association with increased Nrf2ARE binding activity in hepatocytes (25). These results allow us to assemble a series of consequential events as follows: exposure to homocysteine causes GSH depletion that might change the redox status of the cell. This condition might trigger nuclear translocation of Nrf2 and activation of the Nrf2/ARE pathway to up-regulation of enzymes responsible for the synthesis of endogenous antioxidants such as GSH. This auto regulation mechanism could be proposed as a therapeutic target to prevent or reduce stress oxidative induced by homocysteine using pharmaceutical or natural dietary agents. In this context, several dietary compounds have been reported to increase Nrf2 levels, disassociate Nrf2 of its cytosolic inhibitor Keap1 or enhance Nrf2 protein stabilization, resulting in the activation of Nrf2-dependent gene expression (26, 
27). In conclusion, our study showed that homocysteine induces the expression of GCL in HepG2 cells and this induction involves ARE within GCL promoter. We have also shown that this induction is dependent on Nrf2 nuclear accumulation. Increased expression of antioxidant genes via ARE-driven gene regulation could help to protect liver against homocysteine induced oxidative stress. As Nrf2/ ARE pathwayshave been shown to provide protection against several oxidative impact in different organs (2830) and increased expression of GCL decreases fibrogenic response in liver (31). Therefore, targeting of this pathway may be considered as a therapeutic strategy for the protection against oxidative liver damage caused by homocysteine, especially in cases with severe hyperhomocysteinemia due to enzymatic deficiencies accompanied with progressive hepatic steatosis and fibrosis.

\section{Acknowledgements}

The authors are grateful to Mrs Edalat and Dr Sahdat for their technical help for flowcytometry.

\section{Authors' Contribution}

Monireh Mani, Shahnaz Khaghani, Taghi Gol Mohammadi : data collection, design of the study, analysis of data and final revision. Zahra Zamani: final revision. Kayhan Azadmanesh, Reza Meshkani, Parvin Pasalar: data collection and final revision. Ehsan Mostafavi: Statistical analysis.

\section{Financial Disclosure}

Authors have no financial interests related to the material in the manuscript.

\section{Funding/Supports}

This work was financially supported by a grant No.10501from the Tehran University of Medical Science, Iran.

\section{References}

1. Lawrence de Koning AB, Werstuck GH, Zhou J, Austin RC. Hyperhomocysteinemia and its role in the development of atherosclerosis. Clin Biochem. 2003;36(6):431-41

2. Kang SS, Wong PW, Malinow MR. Hyperhomocyst(e)inemia as a risk factor for occlusive vascular disease. Annu Rev Nutr. 1992;12:279-98.

3. El Oudi M, Aouni Z, Mazigh C, Machghoul S. Total homocysteine levels and cardiovascular risk factors in healthy Tunisians. Eas Mediterr Health J. 2011;17(12):937-42.

4. Avila MA, Berasain C, Torres L, Martin-Duce A, Corrales FJ, Yang H et al. Reduced mRNA abundance of the main enzymes involved in methionine metabolism in human liver cirrhosis and hepatocellular carcinoma. J Hepatol. 2000;33(6):907-14.

5. Medici V, Peerson JM, Stabler SP, French SW, Gregory JF, 3rd, Virata $\mathrm{MC}$, et al. Impaired homocysteine transsulfuration is an indicator of alcoholic liver disease. J Hepatol. 2010;53(3):551-7.

6. Mudd SH, Uhlendorf BW, Freeman JM, Finkelstein JD, Shih VE. Homocystinuria associated with decreased methylenetetrahydrofolate reductase activity. Biochem Biophys Res Commun 1972;46(2):905-12.

7. Kang SS, Wong PW, Norusis M. Homocysteinemia due to folate deficiency. Metabolism. 1987;36(5):458-62.

8. Mudd S, Levy H, Skovby F. Disorders of transsulfuration. The metabolic and molecular bases of inherited disease. 1995;1:1279-327.

9. Gaull G, Sturman JA, Schaffner F. Homocystinuria due to cystathionine synthase deficiency: enzymatic and ultrastructural studies. J Pediatr. 1974;84(3):381-90.

10. Adinolfi LE, Ingrosso D, Cesaro G, Cimmino A, D'Anto M, Capasso $\mathrm{R}$, et al. Hyperhomocysteinemia and the MTHFR C677T polymorphism promote steatosis and fibrosis in chronic hepatitis $\mathrm{C} \mathrm{pa-}$ tients. Hepatology. 2005;41(5):995-1003.

11. Robert K, Nehme J, Bourdon E, Pivert G, Friguet B, Delcayre C, et al. Cystathionine beta synthase deficiency promotes oxidative stress, fibrosis, and steatosis in mice liver. Gastroenterology. 2005;128(5):1405-15.

12. Bharathi Devi SR, Suganeswari G, Sharma T, Thennarasu M Angayarkanni N. Homocysteine induces oxidative stress in young adult central retinal vein occlusion. $\mathrm{Br} J$ Ophthalmol. 2012;96(8):1122-6.

13. Dietrich-Muszalska A, Malinowska J, Olas B, Glowacki R, Bald E, Wachowicz B, et al. The oxidative stress may be induced by the elevated homocysteine in schizophrenic patients. Neurochem Res. 2012;37(5):1057-62.

14. Hudson FN, Kavanagh TJ. Cloning and characterization of the proximal promoter region of the mouse glutamate-L-cysteine ligase regulatory subunit gene. Biochim Biophys Acta. 2000;1492(23):447-51.

15. Bea F, Hudson FN, Chait A, Kavanagh TJ, Rosenfeld ME. Induction of glutathione synthesis in macrophages by oxidized low-density lipoproteins is mediated by consensus antioxidant response elements. Circ Res. 2003;92(4):386-93.

16. DeLeve LD, Kaplowitz N, editors. Importance and regulation of hepatic glutathione. Seminars in liver disease; 1990.

17. Kobayashi M, Yamamoto M. Nrf2-Keap1 regulation of cellular defense mechanisms against electrophiles and reactive oxygen species. Adv Enzyme Regul. 2006;46:113-40.

18. Au-Yeung KK, Woo CW, Sung FL, Yip JC, Siow YL, O K. Hyperhomocysteinemia activates nuclear factor-kappaB in endothelial cells via oxidative stress. Circ Res. 2004;94(1):28-36.

19. Wang G, O K. Homocysteine stimulates the expression of monocyte chemoattractant protein-1 receptor(CCR2) in human monocytes: possible involvement of oxygen free radicals. Biochem $J$ 2001;357(Pt 1):233-40.

20. Choi J, Ou JH. Mechanisms of liver injury. III. Oxidative stress in the pathogenesis of hepatitis C virus. Am J Physiol Gastrointest Liver Physiol. 2006;290(5):G847-51.

21. Chowdhury A, Santra A, Bhattacharjee K, Ghatak S, Saha DR, Dhal GK. Mitochondrial oxidative stress and permeability transition in isoniazid and rifampicin induced liver injury in mice. J Hepatol. 2006;45(1):117-26.

22. Perna A, Ingrosso D, De Santo N. Homocysteine and oxidative stress. Amino Acids. 2003;25(3):409-17.

23. Krzywanski DM, Dickinson DA, Iles KE, Wigley AF, Franklin CC, Liu RM, et al. Variable regulation of glutamate cysteine ligase subunit proteins affects glutathione biosynthesis in response to oxidative stress. Arch Biochem Biophys. 2004;423(1):116-25.

24. Bea F, Hudson FN, Neff-Laford H, White CC, Kavanagh TJ, Kreuzer J, et al. Homocysteine stimulates antioxidant response elementmediated expression of glutamate-cysteine ligase in mouse macrophages. Atherosclerosis. 2009;203(1):105-11.

25. Huang CS, Lii CK, Lin AH, Yeh YW, Yao HT, Li CC, et al. Protection by chrysin, apigenin, and luteolin against oxidative stress is mediated by the Nrf2-dependent up-regulation of heme oxygenase 1 and glutamate cysteine ligase in rat primary hepatocytes. Arch Toxicol. 2013;87(1):167-78.

26. Jeong WS, Jun M, Kong AN. Nrf2: a potential molecular target for cancer chemoprevention by natural compounds. Antioxid Redox Signal. 2006;8(1-2):99-106.

27. Kwak MK, Wakabayashi N, Kensler TW. Chemoprevention through the Keap1-Nrf2 signaling pathway by phase 2 enzyme inducers. Mutat Res. 2004:555(1-2):133-48.

28. Cho HY, Reddy SP, Kleeberger SR. Nrf2 defends the lung from oxidative stress. Antioxid Redox Signal. 2006;8(1-2):76-87. 
29. Chen XL, Kunsch C. Induction of cytoprotective genes through Nrf2/antioxidant response element pathway: a new therapeutic approach for the treatment of inflammatory diseases. Curr Pharm Des. 2004;10(8):879-91.

30. Lee JM, Calkins MJ, Chan K, Kan YW, Johnson JA. Identification of the NF-E2-related factor-2-dependent genes conferring protection against oxidative stress in primary cortical astrocytes using oligonucleotide microarray analysis. J Biol Chem. 2003;278(14):12029-38.

31. Ramani K, Tomasi ML, Yang H, Ko K, Lu SC. Mechanism and significance of changes in glutamate-cysteine ligase expression during hepatic fibrogenesis. J Biol Chem. 2012;287(43):36341-55. 